\title{
An Assessment of Organic Carbon Fractions in Paddy and Associated Non-paddy Soils of Upper Brahmaputra Valley of Assam
}

\author{
Zenesia A. Phillips* and R. M. Karmakar \\ Department of Soil Science, Assam Agricultural University \\ Jorhat, India \\ *Corresponding author's email: zenesia_phillips [AT] yahoo.com
}

\begin{abstract}
ABSTARCT---- An investigation was carried out to study the soil organic carbon fractions in paddy and associated non-paddy soils of Assam, India. Three districts viz. Sivasagar, Jorhat and Golaghat in the Brahmaputra valley of Assam were selected for this study. Soil samples were collected from six profiles, three each from mono-cropped paddy and associated non-paddy areas were collected. Horizon -wise, soil samples were analyzed for organic carbon fractions. Organic carbon, Humus $C$, Humin $C$, Humic acid $C$ and Fulvic acid $C$ were all analyzed from the samples. Organic carbon content in soil varied from $0.90-7.90 \mathrm{~g} \mathrm{~kg}^{-1}$. Surface horizons of paddy soils contained lower amounts of humus $C\left(0.255-0.330\right.$ per cent) and fulvic acid $C\left(C_{F A}\right)(0.135-0.180$ per cent) and higher amounts of humin carbon $(0.210$ 0.475 per cent) and humic acid $C\left(C_{H A}\right)(0.120-0.150$ per cent) as compared to that of non-paddy soils $(0.300-0.435$ and 0.195-0.300, 0.180-0.490 and 0.105-0.135 per cent respectively). It was concluded that the ratio of $\left(C_{H A}+C_{F A}\right) / C_{T O C}$ indicated less humification on the surface horizons of paddy soils. This is a direct result of prolonged submergence which led to humic acid carbon becoming less oxidized or humified.
\end{abstract}

Keywords--- Organic carbon, humic acid, fulvic acid, humin, humification, paddy soils

\section{INTRODUCTION}

Soil organic carbon (SOC) is a heterogeneous mixture of simple and complex organic carbon compounds which comes from the products of living organisms. It is the carbon stored within soil and is a part of soil organic matter which comprises of other important elements such as calcium, hydrogen, oxygen and nitrogen. There are four biologically significant types of soil organic carbon fractions identified, each differing in size, hence causing decomposition to go on at different rates. These fractions are: crop residues, particulate organic carbon, humus and recalcitrant organic carbon (Baldock, 2008).

Soil organic carbon plays a vital role in improving soil quality for sustainable crop production. Studies relating to humic substances in soil are important for understanding both soil genesis and management of soil organic matter (SOM). Soil organic carbon is important as it determines ecosystem and agro ecosystem functions, influencing pedogenesis. Greater amounts of organic carbon in paddy soil can be a reflection of intensified humification resulting from increased aggregation (Wang et al., 2015).

It is also of global importance because of its role in the global carbon cycle and, therefore, plays a role in the mitigation of atmospheric levels of green house gases (GHG) with special reference to carbondioxide $\left(\mathrm{CO}_{2}\right)$ due to global warming (Bhattacharya et al., 2008).Organic matter (OM) in soil represents the largest carbon pool and is an important nutrient reservoir in terrestrial ecosystems. Nearly 70 per cent area of India is deficient in soil organic carbon (Velayutham et al., 2000).

Rice (Oryza sativa L.), grown in India is a major cereal crop of Asian origin. Rice occupies about two thirds of the total cropped area in Assam. It is the single major food source, hence significantly contributes to mass agricultural production, therefore playing a significant role in the state economy. Rice in Assam is grown as autumn (ahu), winter (sali) and summer (boro) crop based on the combination of land and hydrological characteristics, maturity duration of rice genotypes, length of growing season and growing conditions. Out of these, sali rice grown during the wet season (June-December) is the most important culture occupying about 70 per cent of the total rice area of state of Assam. This major portion of rice cultivated area particularly in the Upper Brahmaputra Valley Zone (UBVZ) of Assam is under mono-crop (Barah, 2001). Paddy soils are a unique anthropogenic soil type formed under long-term hydro-agric management with seasonal submergence (Gong, 1999).The submergence and puddling during rice cultivation creates conditions which are significantly different from those of non-rice growing areas (Willet, 1979; Gong, 1983).

Undoubtedly, rice cropping, as an important land use, has significant effects on $\mathrm{C}$, and $\mathrm{N}$ cycling around the globe (Lal et al., 1998). It is therefore imperative that studies be carried out in relation to how mono-cropping affects soil organic carbon fractions. Studies of this nature are necessary in assessing damage done to soil over time, and guide in finding ways to 
improve the soil fertility, leading to soil sustainability and continued productivity of this crop. It is commonly accepted that implementation of rice-cropping practices would enhance accumulation of soil organic carbon (Lal, 2002

Soil organic matter (SOM) is a complex mixture of plant and animal residues under various stages of decomposition. These residues or substances are synthesized microbiologically and/or chemically by microorganisms .The organic materials are colonized by microbes which utilizes enzymes to oxidize it, while obtaining energy and carbondioxide. (Schnitzer and Khan,1972). The composition of organic matter is extremely complex because of the nature of the various organic inputs and their different stages of decomposition (Chenu et al., 2014).

Paddy soils are an important accumulator for organic matter (Zhang and He, 2004). The accumulation of organic carbon in soils is influenced by the type of plant material. Sanchez et al. (1982) observed that there was higher organic matter content in tropical soil under forest vegetation as compared to grassland vegetation. However, it was found that the organic matter content under grassland vegetation was higher in temperate regions. Cultivation adversely affects the organic matter content in soil. Soils under normal agricultural practices are subject to be depleted in their organic matter content; however this greatly depends on the management practices carried out in the field (Rudrapa, 1978). Borah and Karmakar (1999) observed that the soil organic carbon content under plantation crop was higher than that under the agricultural crops which might have been attributed to annual addition of more amounts of leaf litters in the soils under plantation crops. But the cultivated soils were characterized by lower quantity of organic matter status as compared to forest and grass vegetation (Karmakar, 1999).Management of paddy soil is believed to be favorable for accumulation of organic matter and its content in paddy soils were found to be statistically higher than that of non- paddy soils (Cai, 1996). In Southeast China, paddy soils have the second largest organic matter stocks and thus a large proportion of terrestrial carbon is conserved in wetland rice soils (Zhao, 1996). It is therefore believed that implementation of rice-cropping practices would enhance accumulation of soil organic C (Lal, 2002).

Organic materials decreased exponentially with increasing depth in paddy soils (Pan et al., 2008).

Soil organic carbon (SOC) decreased exponentially with depth to $100 \mathrm{~cm}$ in paddy soils; a substantial proportion of the total SOC (30-40\%) was stored below the $30 \mathrm{~cm}$ depth. This result suggests that SOC stratification within profiles varies with different pedogenetical types of paddy soils with regards to clay and iron oxyhydrates distribution (Genxing et al., 2008). Soil organic matter accumulation in paddy sub-soil can be explained by downward movement of dissolved organic matter and its stabilization by interaction with iron oxides (Kogel-Knabner et al., 2010). Soil organic carbon (SOC) stratification within profiles varied with different pedogenetical types of paddy soils with regards to clay and iron oxyhydrates distributions, therefore organic materials decreased exponentially with increasing in depth in paddy soils (Genxing et al.,2008).

Soil organic matter can be divided into several fractions depending on their densities. Labile fraction (LF) is the most prominent, partly due to its high turnover rate plus it is easily affected by management systems as well as erosion (Wong et al., 2014).

Labile fractions has been described in various ways by soil scientists, including particulate organic carbon (POC) (53$2000 \mu \mathrm{m}$ ), light fraction organic carbon (LFOC) (density of $<2.0 \mathrm{~g} \mathrm{~cm}^{-2}$ ), readily oxidized carbon (ROC) (easily oxidized by potassium permanganate), soil microbial biomass carbon (SMBC) and dissolved organic carbon (DOC) (Cao et al., 2013).

Schnitzer and Khan (1972), grouped soil organic matter (SOM) into two groups - humic and non humic substances. Humic substances are the dark coloured, amorphous macromolecules, ranging in molecular weight from a few hundred to several thousand; they make up the major organic fraction in soil, which are synthesized by biological, chemical and physical processes. Hayes and Swift (1978), found that humic substances constitute 50 to 80 per cent of SOM and are considered to include the most stable fractions therefore, common fractionations of SOM are based on differences in solubilities of organic constituents under acid and alkali conditions. Humic substances represent approximately 40-60\% of the soil organic matter, including three different fractions, which are defined according to their different stabilities under acid hydrolysis and permanganate oxidation (Paul et al., 2001). Humin $(\mathrm{H})$ is said to be the insoluble fraction of humic substances; humic acid (HA) is the fraction that is soluble under alkaline conditions; and fulvic acid (FA) is the fraction that is soluble under both alkaline and acidic conditions (Sutton and Sposito, 2005). The acid soluble material classified as fulvic acid, invariably contains organic substances classified as non-humic (Stevenson and Elliott,1989). These three humic fractions are of similar structure but differ in molecular weight and functional group content. Humic substances are more stable organic compounds that make up a significant portion of the total organic C and $\mathrm{N}$ in soil (Lal, 1994). Specific fractions of organic matter play an important role in maintaining soil quality and thus could be important for indicating and assessing the impact of management practices (Cambardella and Elliot 1992; Chan, 1997).

Milori et al. (2002) reported an increase in the percentage of humic substances with soil depth across all land uses. Longterm rice cropping has been proven to increase organic $\mathrm{C}$ content and humic acid/fulvic acid ratio; it also causes downward movement of organic C, N, and P, which may result in a number of environmental impacts (Zhang and He, 2004). Studies show that the distribution of humic substances in the soils developed on different physiographic units in lower Brahmaputra valley zone of Assam. Fulvic acid majorly constituted the largest part (47.6-90.0\%) of humus carbon. Humic acid content decreased gradually with soil depth whereas fulvic acid was found to increase in the illuvial 
horizons of Ruptic-Ultic Dystrudepts on piedmont plain and Typic Hapludults on monadnocks (Karmakar and Rao 1999).

Materials:

\section{MATERIALS AND METHODS}

Location and extent: Three districts viz., Sivasagar, Jorhat and Golaghat in the Brahmaputra valley of Assam were selected for the present study. These districts are situated in the Upper Brahmaputra Valley Zone (UBVZ) of Assam and cover an area of $9021 \mathrm{sq}$. $\mathrm{km}$ which is 55.7 per cent of UBVZ. These districts form a part of the southern bank of the Brahmaputra valley of Assam. Six soil profiles, three each from mono-cropped paddy and associated non-paddy areas were collected from Sivasagar, Jorhat and Golaghat districts of Assam. Horizon-wise soil samples were collected from each soil profile.

Preparation of soil samples and analysis: The soil samples were air dried, ground and passed through a $2 \mathrm{~mm}$ sieve. The sieved soil samples were stored in polythene bags and subsequently used for various physico-chemical analyses. Fresh soil samples were stored in refrigerator for microbiological analyses.

Organic carbon was determined by the Walkley and Black's method Jackson (1973)

Sub-fractionation of organic carbon was done by Modified Walkey and Black Chan et al. (2001) method.

Humus $(\mathrm{CH})$, humin $(\mathrm{CHn})$, humic acid carbon (CHA) and fulvic acid carbon (CFA) fractions: Humus carbon content in the $0.1 \mathrm{M}$ Na-pyrophosphate extract was determined by Walkley and Black (1934) method. The difference between organic carbon and humus carbon gives the humin carbon. The extract was acidified with conc. $\mathrm{H}_{2} \mathrm{SO}_{4}$ to precipitate humic acid fraction (Kononova et al., 1966); the precipitate was filtered and dissolved in warm $0.05 \mathrm{~N} \mathrm{NaOH}$ solution. Carbon content in the acid soluble (fulvic acid fraction) and alkali soluble (humic acid fraction) were determined as earlier (Kononova et al., 1966).

\section{Statistical analysis}

Simple correlation analyses were carried out for some selected soil parameters following the procedure outlined by Snedecor and Cochran (1967).

Parameters of intrest included soil organic carbon fractions:

Organic Carbon (OC\%)

Humas Carbon $\left(\mathrm{C}_{\mathrm{H}}\right)$

Humin $\mathrm{C}_{\mathrm{Hn}}$ )

Humic acid $\left(\mathrm{C}_{\mathrm{HA}}\right)$ and

Fulvic acid $\left(\mathrm{C}_{\mathrm{FA}}\right)$

\section{RESULTS AND DISCUSSION}

Soil organic carbon fractions: The data on soil organic carbon fractions are presented in Table 1.1. and Table 1.2.The amount of humus carbon $\left(\mathrm{C}_{\mathrm{H}}\right)$ in soil varied from $0.045-0.330$ per cent in the paddy soils $(\mathrm{P} 1, \mathrm{P} 2, \mathrm{P} 3)$ and $0.030-0.435$ per cent in the non-paddy soils (NP1, NP2, NP3) (Table 4.8). Surface horizons of paddy soils contained lower amount of humus carbon (0.255-0.330 per cent) as compared to that of non-paddy soils (0.300-0.435 per cent). Humus carbon $\left(\mathrm{C}_{\mathrm{H}}\right)$ constituted 16.4 -61.1 per cent of soil organic carbon (SOC) in the paddy soils and 38.0-69.0 of soil organic carbon (SOC) in non-paddy soils (Table 1.2.).

This suggests lower degree of humification in the surface horizon of paddy soils under aquic condition. This is also supported by higher amount of humin $\mathrm{C}$ and lower values of $\left(\mathrm{C}_{\mathrm{HA}} \mathrm{C}_{\mathrm{FA}}\right) / \mathrm{C}_{\mathrm{TOC}}$ ratio in the surface horizons of paddy soils as compared to that in the surface horizons of non-paddy soils (Table 1.1.).The humus $\mathrm{C}$ was significantly and positively correlated with soil organic $\mathrm{C}\left(\mathrm{r}=0.868^{* *}\right)$ and exchangeable $\mathrm{Ca}^{++}\left(\mathrm{r}=0.508^{* *}\right)$ suggest that the degree of humus formation depends on the amount of soil organic carbon and exchangeable $\mathrm{Ca}^{++}$.Soil acidification results in a significant reduction of decomposition rates of organic matter and increases soil carbon accumulation. (Paustian et al.,.1997). Research has shown a $20 \%$ increase in soil exchangeable $\mathrm{Ca}^{++}$due to increased organic fertilizer application (Yan and Hou, 2018). It can therefore be suggested that rice cultivation done over time with the implementation of organic related practices played a major role in increasing SOM while increasing exchangeable $\mathrm{Ca}^{++}$. More exchangeable Ca helps to alter soil acidity, since the exchangeable $\mathrm{Ca}^{++}$ions are attached to the cation exchange sites of the organic matter particles and is strongly absorbed in the soil complex. On the other hand, soil porosity and soil acidity retard the process of humification as indicated by negative correlation of humus $\mathrm{C}$ with bulk density $\left(\mathrm{r}=-0.607^{* *}\right)$ and $\mathrm{pH}(\mathrm{r}=-0.341)$ (Table 1.3.).

The amount of humin carbon $\left(\mathrm{C}_{\mathrm{Hn}}\right)$ in soil varied from $0.011-0.475$ per cent in the paddy soils and $0.030-0.490$ per cent in the non-paddy soils. Surface horizons of paddy soils contained higher amount of humin $\mathrm{C}$ as compared to that of nonpaddy soils except in soils of Nimaigarh Habigaon (Table 4.8). Humin carbon $\left(\mathrm{C}_{\mathrm{Hn}}\right)$ constituted 11.0-65.1 per cent of soil organic carbon (SOC) in the paddy soils and 30.0-80.0 per cent of soil organic carbon (SOC) in the non-paddy soils (Table 1.2.). The humin $\mathrm{C}$ was significantly and positively correlated with soil organic carbon $(\mathrm{r}=0.890 * *)$, exchangeable $\mathrm{Ca}^{++}$ $\left(\mathrm{r}=0.545^{* *}\right)$ and negatively correlated with soil bulk density $\left(\mathrm{r}=-0.533^{* *}\right)$ and $\mathrm{pH}\left(\mathrm{r}=-0.466^{*}\right)$ (Table 1.3.). Humin can be described as the insoluble constituent of soil organic matter (SOM), which remains after extraction of all other 
components of SOM which are soluble under acid or alkali conditions (humic and fulvic acids)(R. Swift et al.,2017).Humin makes the largest component of SOM. Therefore, the more soil organic carbon in the soil will mean more accumulation of humin carbon.

The amount of humic acid carbon $\left(\mathrm{C}_{\mathrm{HA}}\right)$ in soil varied from $0.015-0.150$ per cent in the paddy soils and $0.015-0.135$ per cent in the non-paddy soils (Table 1.1.). Surface horizons of paddy soils contained higher amount of humic acid $\mathrm{C}(0.120-$ 0.150 per cent) as compared to that of non-paddy soils (0.105-0.135 per cent). Humic acid C constituted 4.3-40.0 per cent of soil organic carbon (SOC) in paddy soils and 8.8-23.7 per cent of soil organic carbon (SOC) in non-paddy soils (Table 1.2.). The humic acid $\mathrm{C}$ was significantly and positively correlated with soil organic $\mathrm{C}\left(\mathrm{r}=0.861^{* *}\right)$, exchangeable $\mathrm{Ca}^{++}$ $\left(\mathrm{r}=0.444^{*}\right)$ and negatively correlated with soil bulk density $\left(\mathrm{r}=-0.644^{* *}\right)$ and $\mathrm{pH}\left(\mathrm{r}=-0.453^{*}\right)$ (Table 1.3.).

The amount of fulvic acid carbon $\left(\mathrm{C}_{\mathrm{FA}}\right)$ in soil varied from $0.030-0.180$ per cent in the paddy soils and $0.030-0.300$ per cent in the non-paddy soils (Table 1.1.). Surface horizons of paddy soils contained lower amount of fulvic acid carbon (0.135-0.180 per cent) as compared to that of non-paddy soils (0.195-0.300 per cent). Fulvic acid C constituted 33.3-74.0 per cent of soil organic carbon (SOC) in paddy soils and 17.0-50.0 per cent of soil organic carbon (SOC) in non-paddy soils (Table 1.2.). The fulvic acid $\mathrm{C}$ was significantly and positively correlated with soil organic $\mathrm{C}\left(\mathrm{r}=0.810^{* *}\right)$, exchangeable $\mathrm{Ca}^{++}(\mathrm{r}=0.512 * *)$ and negatively correlated with soil bulk density $(\mathrm{r}=-0.540 * *)$ (Table 1.3.).

During rice cultivation, the $\mathrm{pH}$ of the surface horizon of paddy soils increases due to submergence. This results in formation of more amounts of humic acid in the surface horizon of paddy soils due to elevated soil $\mathrm{pH}$ during rice cultivation. The dominance of fulvic acid carbon over humic acid carbon in the present study is in corroboration with the findings of Borah and Karmakar (1999) and Karmakar and Rao (1999b). The annerobic conditions in the paddy fields and acidic reactions in the studied area are conducive for the formation of fulvic acid over humic acid (Banerjee and Chakravarty, 1977; Karmakar and Rao, 1999b).

Table 1.1. Humus $\left(C_{H}\right)$, humin $\left.C_{H n}\right)$, humic acid $\left(C_{H A}\right)$ and fulvic acid $\left(C_{F A}\right)$ carbon in the soils $(\%)$

\begin{tabular}{|c|c|c|c|c|c|c|c|c|}
\hline Horizon & Depth $(\mathrm{cm})$ & \begin{tabular}{|l} 
Organic \\
carbon \\
$($ OC $)$
\end{tabular} & $\begin{array}{l}\text { Humus } \\
\left(C_{H}\right)\end{array}$ & $C \mid \begin{array}{l}\text { Humin } \\
\left.C_{H n}\right)\end{array}$ & $C \mid \begin{array}{l}\text { Humic acid } \\
C\left(C_{H A}\right)\end{array}$ & $\begin{array}{l}\text { Fulvic acid } C \\
\left(C_{F A}\right)\end{array}$ & $C_{H A} /\left(C_{F A}\right.$ & $\left(C_{H A}+C_{F A}\right) / C_{T O C}$ \\
\hline \multicolumn{9}{|c|}{ Pl (Nimaigarh Habigaon - Paddy soil) : Aquic Dystric Eutrudepts } \\
\hline Ap & $0-15$ & 0.73 & 0.255 & 0.475 & 0.120 & 0.135 & 0.889 & 0.349 \\
\hline$B w 1$ & $15-40$ & 0.47 & 0.195 & 0.275 & 0.075 & 0.120 & 0.625 & 0.415 \\
\hline$B w 2$ & $40-100$ & 0.15 & 0.075 & 0.075 & 0.015 & 0.060 & 0.250 & 0.500 \\
\hline $2 C g$ & $100-120$ & 0.12 & 0.045 & 0.075 & 0.015 & 0.030 & 0.500 & 0.375 \\
\hline \multicolumn{9}{|c|}{ NPl (Nimaigarh Habigaon - Non-paddy soil): Dystric Eutrudepts } \\
\hline Ap & $0-33$ & 0.79 & 0.300 & 0.490 & 0.105 & 0.195 & 0.538 & 0.380 \\
\hline$B w 1$ & $33-55$ & 0.63 & 0.315 & 0.315 & 0.090 & 0.225 & 0.400 & 0.500 \\
\hline$B w 2$ & $55-80$ & 0.55 & 0.270 & 0.280 & 0.090 & 0.180 & 0.500 & 0.491 \\
\hline$B w 3$ & $80-100$ & 0.44 & 0.120 & 0.320 & 0.045 & 0.075 & 0.600 & 0.273 \\
\hline $2 C g 1$ & $100-190$ & 0.15 & 0.105 & 0.045 & 0.030 & 0.075 & 0.400 & 0.700 \\
\hline $2 C g 2$ & $190-220$ & 0.09 & 0.060 & 0.030 & 0.015 & 0.045 & 0.333 & 0.667 \\
\hline \multicolumn{9}{|c|}{ P2 (Silikha Sanaton - Paddy soil): Dystric Fluventic Eutrudepts } \\
\hline$A p$ & $0-15$ & 0.54 & 0.315 & 0.225 & 0.135 & 0.180 & 0.750 & 0.583 \\
\hline$B w$ & $15-55$ & 0.42 & 0.255 & 0.165 & 0.105 & 0.150 & 0.700 & 0.607 \\
\hline$B g 1$ & $55-90$ & 0.39 & 0.195 & 0.195 & 0.045 & 0.150 & 0.300 & 0.500 \\
\hline$B g 2$ & $90-125$ & 0.35 & 0.180 & 0.170 & 0.015 & 0.165 & 0.091 & 0.514 \\
\hline \multicolumn{9}{|c|}{ NP2 (Silikha Sanaton - Non-paddy soil): Dystric Eutrudepts } \\
\hline Ap & $0-10$ & 0.57 & 0.390 & 0.180 & 0.135 & 0.255 & 0.529 & 0.684 \\
\hline$B w 1$ & $10-35$ & 0.48 & 0.255 & 0.225 & 0.075 & 0.180 & 0.417 & 0.531 \\
\hline$B w 2$ & $35-90$ & 0.35 & 0.135 & 0.215 & 0.060 & 0.075 & 0.800 & 0.386 \\
\hline $2 C 1$ & $90-115$ & 0.27 & 0.075 & 0.195 & 0.030 & 0.045 & 0.667 & 0.278 \\
\hline $3 C 2$ & $115-165$ & 0.12 & 0.060 & 0.060 & 0.015 & 0.045 & 0.333 & 0.500 \\
\hline \multicolumn{9}{|c|}{ P3 (Khumtai - Paddy soil): Dystric Eutrudepts } \\
\hline$A p$ & $0-15$ & 0.54 & 0.330 & 0.210 & 0.150 & 0.180 & 0.833 & 0.611 \\
\hline$B w 1$ & $15-50$ & 0.42 & 0.210 & 0.210 & 0.075 & 0.135 & 0.556 & 0.500 \\
\hline$B w 2$ & $50-100$ & 0.27 & 0.150 & 0.120 & 0.045 & 0.105 & 0.429 & 0.556 \\
\hline$B w 3$ & $100-165$ & 0.16 & 0.100 & 0.060 & 0.030 & 0.070 & 0.429 & 0.625 \\
\hline$B g$ & $165-190$ & 0.10 & 0.089 & 0.011 & 0.015 & 0.074 & 0.203 & 0.890 \\
\hline \multicolumn{9}{|c|}{ NP3 (Khumtai - Non-paddy soil): Dystric Eutrudepts } \\
\hline$A p$ & $0-20$ & 0.63 & 0.435 & 0.195 & 0.135 & 0.300 & 0.450 & 0.690 \\
\hline$A B$ & $20-27$ & 0.54 & 0.180 & 0.360 & 0.075 & 0.105 & 0.714 & 0.333 \\
\hline$B w 1$ & $27-60$ & 0.27 & 0.150 & 0.120 & 0.060 & 0.090 & 0.667 & 0.556 \\
\hline$B w 2$ & $60-95$ & 0.17 & 0.045 & 0.125 & 0.015 & 0.030 & 0.500 & 0.265 \\
\hline$B w 3$ & $95-125$ & 0.15 & 0.045 & 0.120 & 0.015 & 0.030 & 0.500 & 0.300 \\
\hline
\end{tabular}


The $\mathrm{C}_{\mathrm{HA}} / \mathrm{C}_{\mathrm{FA}}$ ratio in the studied soils varied from 0.203 to 0.889 in paddy soils and 0.333 to 0.800 in non-paddy soils (Table 1.1.). The surface soils of paddy soils exhibited higher $\mathrm{C}_{\mathrm{HA}} / \mathrm{C}_{\mathrm{FA}}$ ratios $(0.750-0.889)$ as compared to those of nonpaddy soils $(0.450-0.538)$ (Table 4.8$)$. The $\mathrm{C}_{\mathrm{HA}} / \mathrm{C}_{\mathrm{FA}}$ ratio was positively and significantly correlated with soil organic carbon $\left(\mathrm{r}=0.466^{*}\right)$, available $\mathrm{P} 2 \mathrm{O} 5\left(\mathrm{r}=0.384^{*}\right)$ and available $\mathrm{K} 2 \mathrm{O}\left(\mathrm{r}=0.505^{* *}\right)$, and negatively correlated with $\mathrm{pH}(\mathrm{r}=-$ $0.517 * *)$ and bulk density of soil $\left(\mathrm{r}=-0.375^{*}\right)$ (Table 1.3.). The $\mathrm{C}_{\mathrm{HA}} / \mathrm{C}_{\mathrm{FA}}$ ratio of less than unity indicated dominance of fulvic acid in these soils. The long term rice cropping lends for increased humic acid/ fulvic acid ratio ( Zang and He ,2004). The ratio of $\left(\mathrm{C}_{\mathrm{HA}}+\mathrm{C}_{\mathrm{FA}}\right) / \mathrm{C}_{\mathrm{TOC}}$ varied from 0.375 to 0.890 in paddy soils and 0.265 to 0.690 in non-paddy soils (Table 1.1 .). The surface horizons of paddy soils showed lower $\left(\mathrm{C}_{\mathrm{HA}}+\mathrm{C}_{\mathrm{FA}}\right) / \mathrm{C}_{\mathrm{TOC}}$ ratio $(0.349-0.611)$ as compared to the surface horizons of non-paddy soils (0.380-0.690). These suggest less humification (formation of humus) in the surface horizon of paddy soils. The ratio of $\left(\mathrm{C}_{\mathrm{HA}}+\mathrm{C}_{\mathrm{FA}}\right) / \mathrm{C}_{\mathrm{TOC}}$ was positively and significantly correlated with available nitrogen ( $\left.\mathrm{r}=0.426^{*}\right)$ ( Table 1.3.). This suggests that available nitrogen enhances the process of humification. Nitrogen influences and enables the early stage of decomposition because it affects the physiological changes for adaptation of decomposer organisms thus enabling them to function.( Richards, 1987 ).

Table 1.2. Humus $\left(C_{H}\right)$, humin $\left.C_{H n}\right)$, humic acid $\left(C_{H A}\right)$ and fulvic acid $\left(C_{F A}\right)$ carbon in soil as percentage of organic

\begin{tabular}{|c|c|c|c|c|c|}
\hline \multirow{2}{*}{ Horizon } & \multicolumn{5}{|c|}{ carbon } \\
\hline & Depth $(\mathrm{cm})$ & Humus $C\left(C_{H}\right)$ & Humin $C C_{H n}$ ) & Humic acid $C\left(C_{H A}\right)$ & Fulvic acid $C\left(C_{F A}\right)$ \\
\hline \multicolumn{6}{|c|}{ Pl (Nimaigarh Habigaon - Paddy soil) : Aquic Dystric Eutrudepts } \\
\hline$A p$ & $0-15$ & 16.4 & 65.1 & 18.5 & 34.9 \\
\hline$B w 1$ & $15-40$ & 16.0 & 58.5 & 25.5 & 41.5 \\
\hline$B w 2$ & $40-100$ & 10.0 & 50.0 & 40.0 & 50.0 \\
\hline $2 C g$ & $100-120$ & 12.5 & 62.5 & 25.0 & 37.5 \\
\hline \multicolumn{6}{|c|}{ NP1 (Nimaigarh Habigaon - Non-paddy soil): Dystric Eutrudepts } \\
\hline$A p$ & $0-33$ & 38.0 & 62.0 & 13.3 & 24.7 \\
\hline$B w 1$ & $33-55$ & 50.0 & 50.0 & 14.3 & 35.7 \\
\hline$B w 2$ & $55-80$ & 49.1 & 50.9 & 16.4 & 32.7 \\
\hline$B w 3$ & $80-100$ & 27.3 & 72.7 & 10.2 & 17.0 \\
\hline $2 C g 1$ & $100-190$ & 70.0 & 30.0 & 20.0 & 50.0 \\
\hline $2 C g 2$ & $190-220$ & 66.7 & 33.3 & 16.7 & 50.0 \\
\hline \multicolumn{6}{|c|}{ P2 (Silikha Sanaton - Paddy soil):Dystric Fluventic Eutrudepts } \\
\hline$A p$ & $0-15$ & 58.3 & 41.7 & 25.0 & 33.3 \\
\hline$B w$ & $15-55$ & 60.7 & 39.3 & 25.0 & 35.7 \\
\hline$B g 1$ & $55-90$ & 50.0 & 50.0 & 11.5 & 38.5 \\
\hline$B g 2$ & $90-125$ & 51.4 & 48.6 & 4.3 & 47.1 \\
\hline \multicolumn{6}{|c|}{ NP2 (Silikha Sanaton - Non-paddy soil): Dystric Eutrudepts } \\
\hline$A p$ & $0-10$ & 68.4 & 31.6 & 23.7 & 44.7 \\
\hline$B w 1$ & $10-35$ & 53.1 & 46.9 & 15.6 & 37.5 \\
\hline$B w 2$ & $35-90$ & 38.6 & 61.4 & 17.1 & 21.4 \\
\hline $2 C 1$ & $90-115$ & 27.8 & 72.2 & 11.1 & 16.7 \\
\hline $3 C 2$ & $115-165$ & 50.0 & 50.0 & 12.5 & 37.5 \\
\hline \multicolumn{6}{|c|}{ P3 (Khumtai-Paddy soil): Dystric Eutrudepts } \\
\hline$A p$ & $0-15$ & 61.1 & 38.9 & 27.8 & 33.3 \\
\hline$B w 1$ & $15-50$ & 50.0 & 50.0 & 17.9 & 32.1 \\
\hline$B w 2$ & $50-100$ & 55.6 & 44.4 & 16.7 & 38.9 \\
\hline$B w 3$ & $100-165$ & 62.5 & 37.5 & 18.8 & 43.8 \\
\hline$B g$ & $165-190$ & 89.0 & 11.0 & 15.0 & 74.0 \\
\hline \multicolumn{6}{|c|}{ NP3 (Khumtai - Non-paddy soil): Dystric Eutrudepts } \\
\hline$A p$ & $0-20$ & 69.0 & 31.0 & 21.4 & 47.6 \\
\hline$A B$ & $20-27$ & 33.3 & 66.7 & 13.9 & 19.4 \\
\hline$B w 1$ & $27-60$ & 55.6 & 44.4 & 22.2 & 33.3 \\
\hline$B w 2$ & $60-95$ & 26.5 & 73.5 & 8.8 & 17.6 \\
\hline Bw3 & $95-125$ & 30.0 & 80.0 & 10.0 & 20.0 \\
\hline
\end{tabular}


Table 1.3. Correlation coefficients (r) among humus $\left(C_{H}\right)$, humin $\left.C_{H n}\right)$, humic acid $\left(C_{H A}\right)$ and fulvic acid $\left(C_{F A}\right)$ carbon and other soil properties

\begin{tabular}{|c|c|c|c|c|c|c|}
\hline & $\begin{array}{ll}\text { Humus } & C \\
\left(C_{H}\right) & \\
\end{array}$ & $\begin{array}{l}\text { Humic acid } \\
C\left(C_{H A}\right)\end{array}$ & $\begin{array}{l}\text { Fulvic acid } \\
C\left(C_{F A}\right)\end{array}$ & $\begin{array}{l}\text { Humin } \quad C \\
\left(C_{H n}\right)\end{array}$ & $C_{H A} / C_{F A}$ & $\left(C_{H A}+C_{F A}\right) / C_{T O C}$ \\
\hline Sand & 0.007 & 0.066 & -0.030 & -0.222 & 0.172 & 0.061 \\
\hline Silt & -0.005 & -0.065 & 0.032 & 0.262 & -0.155 & -0.100 \\
\hline Clay & -0.009 & -0.059 & 0.022 & 0.142 & -0.172 & -0.003 \\
\hline$p H$ & -0.341 & $-0.453 *$ & -0.247 & $-0.466 * *$ & $-0.517 * *$ & 0.112 \\
\hline Org. $C$ & $0.868 * *$ & $0.861 * *$ & $0.810 * *$ & $0.890 * *$ & $0.466^{*}$ & -0.136 \\
\hline$B D$ & $-0.607 * *$ & $-0.644 * *$ & $-0.540 * *$ & $-0.533 * *$ & $-0.375^{*}$ & -0.043 \\
\hline$E C$ & -0.351 & -0.339 & -0.333 & -0.173 & -0.173 & -0.159 \\
\hline$C E C$ & 0.322 & 0.367 & 0.271 & $0.632 * *$ & 0.318 & -0.346 \\
\hline$K^{+}$ & -0.094 & 0.051 & -0.177 & 0.092 & 0.283 & -0.172 \\
\hline $\mathrm{Na}^{+}$ & -0.092 & 0.012 & -0.150 & -0.269 & 0.167 & 0.175 \\
\hline $\mathrm{Ca}^{2+}$ & $0.508 * *$ & $0.444 *$ & $0.512 * *$ & $0.545^{* *}$ & 0.182 & -0.133 \\
\hline$M g^{2+}$ & 0.289 & 0.205 & 0.320 & 0.341 & -0.019 & -0.027 \\
\hline$B S$ & 0.151 & 0.189 & 0.117 & -0.039 & 0.170 & 0.186 \\
\hline$N$ & $0.596 * *$ & $0.612 * *$ & $0.543 * *$ & 0.252 & 0.272 & 0.196 \\
\hline $\mathrm{P}_{2} \mathrm{O}_{5}$ & $0.612 * *$ & $0.659 * *$ & $0.539 * *$ & $0.717 * *$ & $0.384^{*}$ & -0.153 \\
\hline $\mathrm{K}_{2} \mathrm{O}$ & 0.347 & $0.456 *$ & 0.254 & $0.403 *$ & $0.505 * *$ & -0.209 \\
\hline$M B C$ & $0.624 * *$ & $0.734 * *$ & $0.511 * *$ & 0.318 & $0.561 * *$ & 0.116 \\
\hline
\end{tabular}

Table 1.4. Correlation coefficients $(r)$ among humus $\left(C_{H}\right)$, humin $\left.C_{H n}\right)$, humic acid $\left(C_{H A}\right)$ and fulvic acid $\left(C_{F A}\right)$ carbon

\begin{tabular}{|c|c|c|c|c|c|c|}
\hline & $\begin{array}{l}\text { Humus } C \\
\left(C_{H}\right)\end{array}$ & $\begin{array}{l}\text { Humic acid } \\
C\left(C_{H A}\right)\end{array}$ & $\begin{array}{l}\text { Fulvic } \\
\text { acid } \\
\left(C_{F A}\right)\end{array}$ & $\begin{array}{l}\text { Humin } \quad C \\
\left(C_{H n}\right)\end{array}$ & $C_{H A} / C_{F A}$ & $\begin{array}{l}\left(C_{H A}+C_{F A}\right) \\
/ C_{T O C}\end{array}$ \\
\hline Humic acid $C\left(C_{H A}\right)$ & $0.928 * *$ & 1.000 & & & & \\
\hline Fulvic acid $C\left(C_{F A}\right)$ & $0.973 * *$ & $0.817 * *$ & 1.000 & & & \\
\hline Humin $C\left(C_{H n}\right)$ & $0.547 * *$ & $0.601 * *$ & $0.474 * *$ & 1.000 & & \\
\hline$C_{H A} / C_{F A}$ & 0.289 & $0.599 * *$ & 0.076 & $0.522 * *$ & 1.000 & \\
\hline$\left(C_{H A}+C_{F A}\right) / C_{T O C}$ & 0.281 & 0.160 & 0.335 & $-0.492 * *$ & $-0.374 *$ & 1.000 \\
\hline
\end{tabular}

\section{CONCLUSION}

Soil organic carbon fractions

1. Humus $\mathrm{C}\left(\mathrm{C}_{\mathrm{H}}\right)$ in soil varied from $0.045-0.330$ per cent in the paddy soils and $0.030-0.435$ per cent in the non-paddy soils. Humus $\mathrm{C}$ constituted 10.0-89.0 per cent of soil organic carbon (SOC) in the paddy soils and 26.5-69.0 percent of SOC in non-paddy soils.

2. Humin $\mathrm{C}\left(\mathrm{C}_{\mathrm{Hn}}\right)$ in soil varied from $0.011-0.475$ per cent in the paddy soils and $0.030-0.490$ per cent in the non-paddy soils, which constituted to 11.0-65.1 per cent of SOC in the paddy soils and 30.0-80.0 per cent of SOC in the nonpaddy soils.

3. Humic acid $\mathrm{C}\left(\mathrm{C}_{\mathrm{HA}}\right)$ in soil varied from $0.015-0.150$ per cent in the paddy soils and $0.015-0.135$ per cent in the nonpaddy soils, which constituted to 4.3-40.0 per cent of SOC in paddy soils and 8.8-23.7 per cent of SOC in non-paddy soils.

4. Fulvic acid $\mathrm{C}\left(\mathrm{C}_{\mathrm{FA}}\right)$ in soil varied from $0.030-0.180$ per cent in the paddy soils and $0.030-0.300$ per cent in the nonpaddy soils, which constituted to 33.3-74.0 per cent of SOC in paddy soils and 17.0-50.0 per cent of SOC in nonpaddy soils.

5. Surface horizons of paddy soils contained lower amount of humus $C\left(0.255-0.330\right.$ per cent) and fulvic acid $C\left(C_{F A}\right)$ (0.135-0.180 per cent) and higher amount of humin carbon $(0.210-0.475$ per cent $)$ and humic acid $\mathrm{C}\left(\mathrm{C}_{\mathrm{HA}}\right)(0.120$ 0.150 per cent), as compared to that of non-paddy soils $(0.300-0.435)$ and $(0.195-0.300 ; 0.180-0.490$ and $0.105-0.135$ per cent respectively).

6. $\mathrm{C}_{\mathrm{HA}} / \mathrm{C}_{\mathrm{FA}}$ ratio indicated dominance of fulvic acid these soils.

7. The ratio of $\left(\mathrm{C}_{\mathrm{HA}}+\mathrm{C}_{\mathrm{FA}}\right) / \mathrm{C}_{\mathrm{TOC}}$ indicated less humification in the surface horizons of paddy soils. 


\section{BIBLIOGRAPHY}

- Baldock, A. and Skjemstad, O. (2008). Role of the soil matrix and minerals in protecting natural organic materials against biological attack. Article: Organic Geochemistry, 31:697-710.

- Borah, K. and Karmakar, R. (1999). Distribution of humic substances in soils under different land uses. Journal of Agricultural Science Society of NE India, 12(1):1-8.

- $\quad$ Bhattacharrya, T., Pal, K., Chandran, P., Mandal, C., and Telpande, B. (2008). Soil carbon storage capacity as a tool to prioritize areas for carbon sequestration. Current Science 95:482-494.

- Cai, Z. (1996). Effect of land use on organic carbon storage in soils of eastern china. Water Air Soil Pollution 91: 383 - 393.

- Cambardella, C. A. and Elliot, E. T. (1992). Particulate soil organic matter changes across grassland cultivation sequence. Soil Science Society of America Journal 56: 777-783.

- Chan, K. Y. (1997). Consequences of changes in particulate organic carbon in Vertisol under pasture and cropping. Soil Science Society of America Journal 61: 1376-1382.

- Chenu C., Rumpel C. \& Lehman J. (2014). Chapter 13 - Methods for studying soil organic matter: nature, dynamics, spatial accessibility, and interactions with minerals. In: Eldor A.P., ed. Soil microbiology, ecology and biochemistry. $4^{\text {th }}$ ed. Oxford, UK: Elsevier.

- Genxing, P., Laosheng, W., Lianqing, L., Xuhui, Z., Gong, W. and Yvonne, W. (2008). Organic carbon stratification and size distribution of three typical paddy soils from Taihu Lake region, China. Journal of Environmental Science 20:456-463.

- $\quad$ Gong, Z. (1983). Pedogenesis of paddy soil and its significance in soil classification. Soil Science 135:5-10.

- Gong, Z. (1999). Soil Taxonomic classification of China: Theory, Methodology and Applications, pp 109-164. Science Press, Beijing.

- Hayes, M. and Swift, R. (1978). The Chemistry of soil organic colloids. The Chemistry of Soil Constituents. Wiley Inter- science. Chichester. 179-320.

- Karmakar, R. and Rao, A. (1999). Soils on different physiographic units in Lower Brahmaputra Valley zone of Assam. III. Humic substances. Journal of the Indian Society of Soil Science 47: 771-774.

- Kogel-Knabner, I., Amelung, W., Cao, Z., Fiedler, S. and Frenzel, P. (2010). Biogeochemistry of paddy soils. Geoderma 157:1-14.

- Lal, R. (1994). Tillage effect on soil degradation, soil resilience, soil quality and sustainability, Soil and Tillage. Research 29:1-8.

- Lal, R. (2002). Soil carbon sequestration in China through agricultural intensification, and restoration of degraded and desertified ecosystems. Land Degradation and Development 13:469-478.

- $\quad$ Milori, D., Martin-Neto, L., Bayer, C., Melniczuk, J. and Bagneto, V. (2002). Humification degree of soil humic acid determined by fluorescence spectroscopy. Soil Science 167:737-749

- Pan, G., Wu, L., Li, L., Zhang, X., Gong, W. and Wood, Y. (2008). Organic carbon stratification and size distribution of three typical paddy soils from Taihu Lake Region, China. Journal of Environmental Science 20(4):456-463.

- Paustian, K., Collins, H. and Paul, E. (1997). Management controls on soil organic carbon in soil organic matter in temperate agro ecosystems. Long-term experiments in North America. CRC Press, Boca Raton, FL., pp.. 1549.

- Paul, E., Collins, H. and Leavitt, S. (2001). Dynamics of resistant soil carbon of Midwestern agricultural soils measured by naturally occurring ${ }^{14} \mathrm{C}$ abundance. Geoderma 104:239-256.

- $\quad$ Richards, B. (1987). The microbiology of terrestrial ecosystems. Harlow: Longman. Pp.399

- Rudrappa, T. (1978). The analytical characteristics of humic acids extracted from Malnad soils of Karnataka, Mysore. Journal of the Indian Society of Soil Science 12: 233-238.

- Sanchez, P., Gichuru, M. and Katz, L. (1982). Organic matter in major soils of the tropical and temperate regions. In : Symposia papers I, Transactions of the $12^{\text {th }}$ International Congress of Soil Science New Delhi. pp. 99-144.

- Schnitzer, M. and Khan, S. (1972). Humic substances in the environment. Marcel Dekker, Inc. New York.

- Stevenson, F. and Elliott. E. (1989). Methodologies for assessing the quality and quantity of soil organic matter. In: Coleman, D.e., Oades, J.M. and Uehara, G., eds., Dynamics of Soil Organic Matter in Tropical Ecosystems. Honolulu, Hawaii. University of Hawaii Press. 173-199.

- Sutton, R. and Sposito, G. (2005). Molecular structure in soil humic substance: New view Environmental Science and Technology 39:9009-9016.

- Swift, R., Maylotte, R. and Hayes, M. (2017). Humin: Its composition and importance in soil organic matter. Advances in Agronomy. doi:10.1016/bs .agron. 
- Velayutham, M., Pal, D. and Bhattacharyya, T. (2000). Organic carbon stock in soils of India. In: Global climatic change and tropical ecosystems. Lal, R.; Kimble, J.M. and Stewart, B.A.(eds.).Lewis publishers, Boca Raton, F.L., pp.71-79.

- Wang, P., Liu, Y., Li, L., Cheng, K., Zheng, J., Zhang, X., Zheng, J., Joseph, S., Pan, G. (2015). Long-term rice cultivation stabilizes soil organic carbon and promotes soil microbial activity in a salt marsh derived soil chronosequence. Scientific reports, 5, 15704. doi:10.1038/srep15704

- Wang, R., Filley, T., Xu, Z., Wang, X., Li, M., Zhang, Y. and Jiang, Y.(2014) Coupled response of soil carbon and nitrogen pools and enzyme activities to nitrogen and water addition in a semi-arid grassland of Inner Mongolia. Plant Soil. ; 381(1-2):323-336. doi: 10.1007/s11104-014-2129-2.

- Willet, I. (1979). The effects of flooding for rice culture on soil chemical properties and subsequent maize growth. Plant Soil 52:373-383.

- Yan,B. and Hou, Y. (2018). Soil chemical properties at different toposequence and fertilizers under continous rice production - A review. IOP Conf. Ser.: Earth Environmental Sci. 170032107

- Zhao, C. (1996). Effect of land use on organic carbon storage in soils in eastern China. Water Air Soil Pollution 91: 383-393.

- Zhang, M. and He, Z. (2004). Long term changes in organic carbon and nutrients of an Ultisol under rice cropping in south east China, Geoderma 118: 167 - 179. 